\title{
APLIKASI BAURAN PEMASARAN PADA BISNIS KECIL STUDI KASUS PADA BARRACKS.CAFE
}

\author{
RANI NOVITASARI \\ MUMUH MULYANA \\ Sekolah Tinggi Ilmu Ekonomi Kesatuan
}

\begin{abstract}
Abstrak
Bisnis Kopi di bagian hilir berbentuk café sudah sedemikian marak dengan berbagai bentuk dan diferensiasi. Barracks. Cafe yang berlokasi di Puncak Cisarua Bogor adalah salah satunya. Café yang memiliki karyawan lima orang ini berdiri sebagai UKM yang menggarap remaja yang menjadikan tempat nongkrong sebagai destinasi kesehariannya di akhir pekan. Penerapan strategi bauran pemasaran yang meliputi strategi produk, penetapan harga, promosi dan lokasi telah diterapkan café tersebut.
\end{abstract}

Keywords: Café, Kopi, UKM, Bauran Pemasaran

\section{"BARRACK.CAFE"}

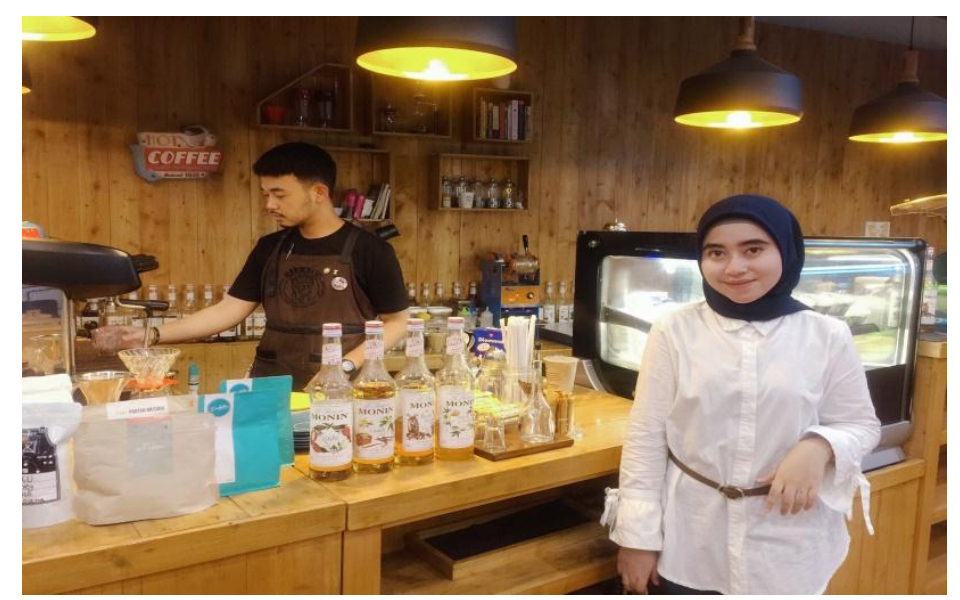

Sejarah barracks.cafe Barracks.cafe ialah salah satu tempat kopi didaerah Barokah, Jalan Raya Puncak KM 79 (Rest Area Centra Kuliner Sari, Kopo, Kec. Cisarua, Bogor, Jawa Barat 16750 . Barrack.cafe berdiri sejak tahun 2018 dengan karyawan berjumlah 5 orang.

Positioning barracks.cafe Barracks.cafe tersebut sebagai tempat nongkrong para remaja dengan harga yang terjangkau oleh masyarkat disekitarnya. 
Segmentasi barracks.cafe Target utama penjualan barrack.cafe adalah para remaja karena sesuai dengan produk yang ditawarkan terutama produk kopi itu sendiri yang banyak diminati oleh para remaja atau yang berlanjut usia. Dan kelebihan dibarracks.cafe itu sendiri selalu ada live musik every Saturday night dari jam 19.00 - 23.00.

Produk barracks.cafe Menawarkan berbagai produk yang cukup bervarasi, barrack.cafe itu sendiri mempunyai cirikhas prdouk kopi tersendiri yaitu kopi barrack dengan harga yang sangat terjangkau yaitu RP.20k. tapi jangan khawatir dibarrack.care ini banyak rasa rasa kopi yang lainnya misalnya Cold new,milky barrack, japanese ice drip coffe with sumatra, ice cappucino,hot mochacino dan Dll.selain ada kopi juga disana ada makanan berat dan ringan. Promotionbarracks.cafe Cara memperkenalkannya progman tersebut kepada konsumen dengan membrikan informasi atau mengshare barracks.cafe ini melalui sosoal media seperti instagram ( foto-caption-upload) serta memasang bannerdepan toko tersebut bisa memudahkan setiap pengunjung yang mau ke tempat barracks.cafe.

Place barrack.cafe Barokah, Jalan Raya Puncak KM 79 (Rest Area Centra Kuliner Sari, Kopo, Kec. Cisarua, Bogor, Jawa Barat 16750 Jam Buka · Tutup pukul 23.00 . tempat parkir yang begitu luas.

Menu yang begitu banyak dan tempat yang sangat strategis karna barracks.cafe ini berada dipinggir jalan jadi secara tidak langsung penikmat kopi bisa langsung berenti dan mencari tempat parkir motor/mobil. Barracks.cafe ini sudah memiliki cabang sendiri didaerah Rest area sari barokah Gadog.

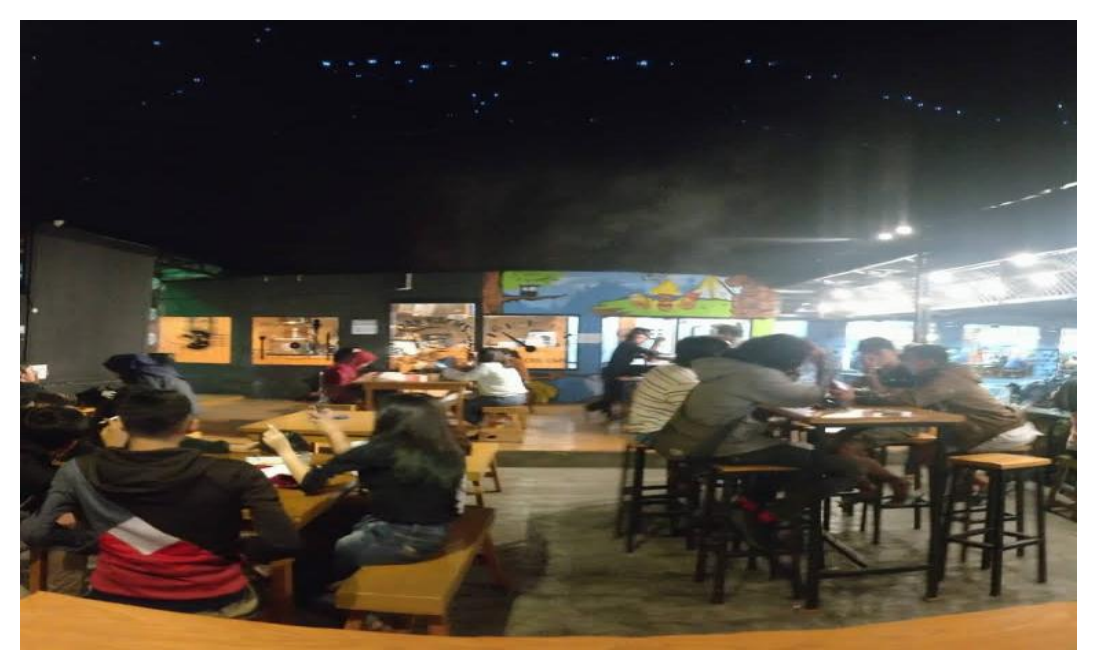

Price barracks.cafe Harga produk yang ditawarkan begitu terjangkau dan bersahabat, cara menentukan harga yang akan dijual dengan melihat daya beli masyarakat yang ada disekitar barracks.cafe. sistem pembayaran dibarracks.cafe itu dengan cara memesan terlebih dahulu 
seusai keinginan lalu bayar ditempat nanti pesanan kita diantar. Pembayaran itu sendiri bisa cash atau debit.

Strategi barracks.cafe sebenarnya didaerah cisarua bogor belum begitu banyak yang membuka cafe kopi maka dari itu pesaingnya juga belum begitu ketat. Tetapi dengan lebih meningkatkan cita rasa kopi sendiri itu bisa jauh kebih baik dan cara melayani konsumen harus dengan ramah cepat dan baik.

Referensi :

Hidayat, L., Mulyana, M., \& Effendy, M. (2018). Membangun Kepuasan Mahasiswa Pengguna Laboratorium Komputer. JAS-PT Jurnal Analisis Sistem Pendidikan Tinggi, 1(2), 93-101.

Mariyah, M. and Mulyana, M. (2015). ARTICLE REVIEW OF HUMAN CAPITAL, ECONOMIC STRUCTURE AND GROWTH. Jurnal Dosen STIE Kesatuan.

Mulyana, M. (2012). Consumer Behaviour: Sukses Dengan Memahami Konsumen. ISBN 978-979-18531-6-3, Bogor: Kesatuan Press.

Mashadi, M., \& Irawan, R. (2017). Model Struktural Minat Mahasiswa Berkarir di Bidang Perbankan Syariah Sebagai Dasar Pengembangan Proses Pembelajaran. JAS-PT Jurnal Analisis Sistem Pendidikan Tinggi, 1(1), 1-10.

Mulyana, M. and Sulistiono, S. (2012). Kewirausahaan: The Long Life Way of Business.

Munandir. 1996. Program Bimbingan Karier di Sekolah. Jakarta: Direktur Jenderal Pendidikan Tinggi.

Nurendah, Y., Mulyana, M., \& Muanas, M. (2018). Evaluasi dan Pemetaan Minat Studi Siswa SMA dan SMK di Kota Bogor Pada Program Studi Ekonomi Syariah. JAS-PT Jurnal Analisis Sistem Pendidikan Tinggi, 2(2), 83 - 94.

Nurendah, Y. and Mulyana, M. (2013). Analisis Pengaruh Kualitas Pelayanan Perpustakaan Terhadap Kepuasan dan Hubungannya dengan Loyalitas Mahasiswa. Jurnal Ilmiah Manajemen Kesatuan, 1(1), pp.91-105.

Sulistiono, S., Nurendah, Y., \& Mulyana, M. (2019). Mengukur Minat Studi Siswa SMA dan SMK di Kota Bogor Pada Program Studi Kewirausahan. JAS-PT Jurnal Analisis Sistem Pendidikan Tinggi, 3(1), 1 - 12.

Manurung, T. (2017). Pengaruh Motivasi dan Perilaku Belajar Terhadap Prestasi Akademik Mahasiswa. JAS-PT Jurnal Analisis Sistem Pendidikan Tinggi, 1(1), 17-26. Retrieved from http://journal.fdi.or.id/index.php/jaspt/article/view/36 
Sastra, H. (2018). MINAT BERINVESTASI MAHASISWA DAN KUALITAS PELAYANAN GERAI BURSA EFEK INDONESIA STIE KESATUAN BOGOR. JAS-PT Jurnal Analisis Sistem Pendidikan Tinggi, 2(1), 1 - 12.

Mulyana, M. and Khrisnayoga, P.P., 2019. OBSERVASI PERILAKU KONSUMEN DALAM BERBELANJA ONLINE.

Mulyana, M., 2019. MENGANALISIS PERILAKU KONSUMEN. 